\title{
The World of Jia Zhangke
}

An interview with the director of Xiao Wu, Platform, Unknown Pleasures and The World

Patricia R.S. Batto

\section{(2) OpenEdition}

\section{Journals}

\section{Édition électronique}

URL : http://journals.openedition.org/chinaperspectives/2843

DOI : $10.4000 /$ chinaperspectives.2843

ISSN : 1996-4617

Éditeur

Centre d'étude français sur la Chine contemporaine

\section{Édition imprimée}

Date de publication : 1 août 2005

ISSN : 2070-3449

Référence électronique

Patricia R.S. Batto, «The World of Jia Zhangke », China Perspectives [En ligne], 60 | july - august 2005, mis en ligne le 09 avril 2008, consulté le 28 octobre 2019. URL : http://journals.openedition.org/ chinaperspectives/2843; DOI : 10.4000/chinaperspectives.2843

Ce document a été généré automatiquement le 28 octobre 2019

(c) All rights reserved 


\section{The World of Jia Zhangke}

An interview with the director of Xiao Wu, Platform, Unknown Pleasures and The World

\section{Patricia R.S. Batto}

Social reality is very present in your films...

1 Ever since I began directing, I have tried in my films to follow the changes in Chinese society. I was born in 1970; during my childhood I witnessed the end of the Cultural Revolution, and then the beginning of the era of reform and change. If you look at the time in which my films are set, the second, Platform, takes place between 1971 and 1990 , the story of Xiao Wu is set in the mid-1990s, Unknown Pleasures around the year 2000, and my latest film, Shijie, takes place in the present. In this way I hope I have succeeded in filming the lives of Chinese youth from the end of the Cultural Revolution up to today.

Why the young in particular?

2 Because it's young people that I know best. Also, because I think that young people in China are faced with a number of problems. China is governed by old men, who do not trust the young. The young are under enormous pressure. I think attention needs to be paid to these young people, and to what they have to say to us.

When they speak, nobody listens. What's more they have very few opportunities to express their ideas, to assert their points of view about society, which is why I choose to talk about them in my films.

What problems do you think about? Unemployment?

4 No, youth unemployment is a recent problem. I think more about the aspiration to freedom, which comes up against limitations. Another is the fact that all the economic and political resources are monopolised by a minority; this is an injustice which affects the future of young people as a whole.

5 For example, a young person living in the city and a young person living in the country do not have access to the same resources at all, nor do they have the same rights. Or again, depending on the social position of their parents, a young person's life will be 
easy or not so easy. That's unjust. I think there is a problem of access to resources, a question of justice and of equity.

The young often seem desperate in your films...

6 Yes, they don't know how to cope. They are lost (mimang), completely lost.

Your films verge on the documentary...

7 I make documentaries as well. I've shot two, the first is You yitian zai Beijing (One Day in Peking), the second Gongzhong de changsuo (In Public). But a work of fiction and a documentary are two different things. For example, relationships between people, between individuals, are paradoxically easier to show in fiction. It is easier to realise certain realities in fiction, and they appear more authentic. Say I wanted to film my relationships with my friends, or that someone else wanted to film them; we might not be able to film the real relationship, it will remain elusive to the camera because people won't reveal themselves. Whereas in fiction the order of things, everyday life, can be filmed. Fiction is better suited for certain things, and can show them with greater accuracy, particularly some dimensions of reality that I want to show.

When you make a documentary, and you want to raise certain questions, people do not necessarily want to talk about their private lives. There's a danger of filming only appearances. It's even more difficult with ordinary people, and they are the ones I want to talk about.

9 If I wanted to make a film about handicapped people, I wouldn't go and film people who were really disabled.

You often film marginalised people, people who have not benefited from the reforms...

Contemporary Chinese reality is multifarious. Each of us is faced with a different reality. I often use the example of somebody going to Shanghai: if they go by plane, they will see one reality; if they go by train, they will see a different reality; going by boat will be different again. Through this prism of methods of transport in China alone, Chinese reality is shown to have a multitude of faces.

It's not that I don't know the life of the nouveaux riches, I'm just not interested in filming it. What touches and moves me, what I want to film, is the life of ordinary people.

Chinese people feel inequality very strongly in their daily lives. They know all about inequality, it's no secret, everybody is aware of it. At the present time, the strongest source of discontent in China is this split (fenhua) between the rich and the poor.

For example, in my native province, Shanxi, there are a large number of coal mines, most of which are privately owned. Accidents are frequent, and many miners die as a result. The owners of these mines can be very rich. A family may decide to buy a car, and they'll buy perhaps ten of them at once, one for each member of the family. Everyone sees the kind of life they lead, and that it's different.

Your films are often in dialect rather than in Mandarin...

14 I like dialects, and there are many of them. A lot more things can be expressed in dialect than in Mandarin (putonghua). And when the actors speak in their own dialect -which is their mother tongue, everyone learns Mandarin later-, when the actors use their mother tongue, they are very natural. The actress Zhao Tao speaks Shanxi dialect, while the actor Wang Hongwei speaks Henan dialect, which is closely related to it.

The world of entertainment and its artists play a major part in your films. What do you see as being the role of culture in contemporary China? 

entertainment is going through enormous changes. At the beginning of Platform, theatrical productions still resemble the shows of the Cultural Revolution. Little by little, there's a shift towards light music. In Unknown Pleasures, entertainment and song are used to sell alcohol; they are a form of advertising for a brand of alcohol. In World, one has the impression of watching a fashion show in Paris or in Milan. The world of entertainment is very revealing of the changes in Chinese society, which is turning more and more towards consumerism. It's very obvious.

Why do you have Russians in your most recent film? and also a lot of Latin Americans. I prefer the Russians, because I think that, in the past, we had a comparable political environment. I think that we have characteristics in common; although China is evolving slowly, we experienced the same ideology. That's why there are Russians in Shijie.

What role does the cinema play in China? people who knew about film considered it an instrument of political propaganda. There were some who also thought that film was an artform. These two points of view coexisted. But nobody thought that film could be an industry. Now we have gone from one extreme to the other: apparently, film now can only be an industry.

Most of the films shown in China are American. There is no longer the idea of a diversified film culture. It's a dangerous situation. In the last few years, the audience has grown used to seeing only American films. It's a serious problem.

Your first three films were banned in China, and only the most recent one was shown in the cinemas. What relationship do you have with your audiences in China?

Since my first films were not authorised, initially I met my audiences in the universities or in bars. Later, thanks to pirate DVDs, a lot of people were able to see my films. To discuss them the most important tool is the Internet. A lot of people talk about film on the Internet. Also, later on, some of the media-especially in the south-showed daring and courage, and talked about me.

20 I feel that part of my responsibility as a Chinese person is to bear witness, to make Chinese reality known; I don't differentiate between Chinese and foreign audiences, I think that everyone can watch my films. I don't think that there are some things more aimed at Chinese audiences and others at foreign audiences. It's open, and everyone can watch.

21 To me there is still an objective: helping to understand Chinese reality, because, in fact, many people are submerged by reality, they are intensely involved in it. Not everyone understands what is happening, far from it. Perhaps some people do not need to understand...

Since 1979, the Chinese have been seized by a frenzied desire to know about the world, about other cultures, other countries. This frenzy continues in the present; the theme parks with reproductions of the world's most famous monuments are part of this, they are an answer to this frenzy. But it's hard to know what people can understand from these parks; the more often they visit them, the more absurd and over the top it becomes.

How do you feel about being probably better known abroad than in China?

China Perspectives, 60 | july - august 2005 


\section{RÉSUMÉS}

Jia Zhangke, born in 1970 in Fenyang in the province of Shanxi, attended the School of Fine Arts in Taiyuan before entering the Beijing Film Academy in 1993. he graduated in 1997 and also directed his first film Xiao Wu (Xiao Wu). In 2000 he made Platform (Zhantai) and, in 2002, Unknown Pleasures (Ren xiao yao). The World (Shijie) is his most recent film. 